\title{
Genomic profiling of B-progenitor acute lymphoblastic leukemia
}

\author{
Charles G. Mullighan, MD, PhD ${ }^{\star}[$ Assistant Member] \\ Department of Pathology, St Jude Children's Research Hospital, 262 Danny Thomas Place, \\ Memphis, TN 38112
}

\begin{abstract}
Childhood acute lymphoblastic leukemia is comprised of multiple subtypes defined by recurring chromosomal alterations that are important events in leukemogenesis and are widely used in diagnosis and risk stratification, yet fail to fully explain the biology of this disease. In the last 5 years, genome-wide profiling of gene expression, structural DNA alterations and sequence variations has yielded important insights into the nature of submicroscopic genetic alterations that define novel subgroups of acute lymphoblastic leukemia (ALL) and that cooperate with known cytogenetic alterations in leukemogenesis. Importantly, several of these alterations are important determinants of risk of relapse and are potential targets for therapeutic intervention. Here, these advances and future directions in the genomic analysis of ALL are discussed.
\end{abstract}

\section{Keywords}

ALL; acute lymphoblastic leukemia; genomic profiling; B-progenitor; IKZF1; BCR-ABL1-like; PAX5; JAK1/2; CRLF2; CREBBP

\section{Introduction}

Acute lymphoblastic leukemia (ALL) is the commonest childhood malignancy, and despite cure rates now exceeding $80 \%$ [1], remains the leading cause of non-traumatic death in children and young adults [2]. Moreover, although ALL is less common than acute myeloid leukemia (AML) in the older adults, cure rates decline with increasing age. Consequently, there is intense interest in identifying genetic and biologic features that influence the pathogenesis of ALL and the risk of treatment failure [3]. In particular, the last 5 years have witnessed an explosion of activity in the use of high resolution genomic approaches to comprehensively identify all genetic alterations in leukemic cells [4-6].

Childhood ALL is characterized by recurring cytogenetic alterations including aneuploidy and recurring chromosomal translocations (Figure 1) [7, 8]. Hyperdiploidy with gain of at least 5 chromosomes is one of the most common types of ALL and is associated with excellent outcome; in contrast, hypodiploidy with less than 44 chromosomes is associated with a very poor prognosis [9-13]. Translocations in childhood ALL commonly disrupt

\footnotetext{
(C) 2011 Elsevier Ltd. All rights reserved.

*Tel: +1 (901) 595-3387, Fax: +1 (901) 595-5947, Charles.mullighan@stjude.org.
}

Conflict of interest statement

No relevant financial relationships with nay commercial interest.

Publisher's Disclaimer: This is a PDF file of an unedited manuscript that has been accepted for publication. As a service to our customers we are providing this early version of the manuscript. The manuscript will undergo copyediting, typesetting, and review of the resulting proof before it is published in its final citable form. Please note that during the production process errors may be discovered which could affect the content, and all legal disclaimers that apply to the journal pertain. 
hematopoietic transcription factors or activate oncogenes and are key events in leukemogenesis. These include the (usually cryptic) $\mathrm{t}(12 ; 21)$ ETV6-RUNX1 [14, 15], $\mathrm{t}(1 ; 19)$ $T C F 3-P B X 1, \mathrm{t}(9 ; 22) B C R-A B L 1$, and rearrangement of $M L L$. Similarly, T-lineage ALL is characterize by recurring rearrangements that commonly juxtapose regulatory elements of the T-cell antigen receptor loci with transcription factor or homeobox genes [16]. Recent findings from genomic analysis of T-lineage ALL are beyond the scope of this review and the reader is referred to recent review of the field [16-18]. These alterations are central events in leukemogenesis and identification of these rearrangements is vital in accurate risk stratification for therapy [3]. However, several observations indicate that these alterations are insufficient to explain the biologic basis of ALL and response to therapy. A substantial minority of children and a high proportion of adults lack one of these rearrangements [8]. Moreover, in experimental models, these alterations commonly do not alone induce leukemia, indicating that additional genetic or epigenetic alterations are required. Identification of these additional genetic alterations has been limited by conventional cytogenetic approaches, which typically can only detect gross rearrangements or structural alterations more than several megabases in size. Until recently, detection of additional genetic alterations has been reliant on candidate gene analysis, which has identified a small range of additional genetic changes, such as deletion of $C D K N 2 A / C D K N 2 B$ (encoding INK4/ARF) and sequence mutation of NOTCHI in T-ALL [19, 20].

\section{Genome-wide profiling of ALL}

The completion of the human genome project and the development of microarray technologies to profile gene expression and structural genetic alterations at high resolution have revolutionized our ability to identify genetic alterations in cancer genomes. These approaches have been applied to large cohorts of ALL cases by several groups [21-27] and have transformed our understanding of the genetic basis of this disease.

Microarray gene expression profiling has demonstrated that known recurring cytogenetic alterations in ALL are associated with distinct gene expression profiles [28] and also identify novel subgroups of ALL lacking known structural genetic alterations [29, 30]. These studies have provided important insights into the pathways dysregulated in ALL, but are unable to directly identify novel or cooperating genetic alterations contributing to leukemogenesis. From 2006, several groups have used microarray approaches to identify structural genetic alterations at high resolution. These include microarray comparative genomic hybridization (array-CGH) that compares DNA content of tumor and references normal samples to identify regions of DNA loss or gain; and single nucleotide polymorphism (SNP) arrays that genotype millions of common inherited SNPs across the genome [31]. While originally designed primarily as a genotyping tool to facilitate genomewide association studies (GWAS) that identify inherited genetic variants that are associated with a disease phenotype, SNP arrays also permit inference of DNA copy number state, and by comparing tumor and normal SNP genotypes, can detect copy-neutral loss-ofheterozygosity $(\mathrm{LOH})$ that may indicate duplication of a mutated tumor suppressor gene or oncogene [32].

Several groups have performed detailed evaluation of DNA copy number alteration and LOH in large cohorts of childhood ALL. Notably, at this time, detailed analyses of large cohorts of adolescent, young adult, and older adult ALL cases are lacking [33]. Nonetheless, these studies have utilized array-CGH and SNP microarray platforms that interrogate up to 2 million markers across the genome, with the ability to detect genetic alterations at sub 5 kilobase resolution. In a study of 242 childhood B-progenitor ALL cases, we used Affymetrix SNP microarrays and detected over 50 regions of recurring genetic alteration [21]. Many of these were not evident on cytogenetic analysis, were less than one megabase 
in size, and commonly involved only a single or few genes, directly implicating alteration of these genes in leukemogenesis. Many of the targets of alteration were logical candidates in leukemogenesis, including tumor suppressor and cell cycle regulatory genes $(C D K N 2 A / B$, $P T E N, R B 1$ ), transcription factors and transcriptional coactivators (ETV6, ERG, TBLIXRI), as well as genes involved in lymphoid maturation and signaling that have not previously been studied (eg, BTLA/CD200, TOX) and genes involved in drug responsiveness (eg, the glucocorticoid receptor $N R 3 C 1$ ). A notable finding was that genes encoding transcriptional regulators of B-lymphoid development were mutated by deletion, translocation of sequence mutation in over two-thirds of B-progenitor ALL cases (Table 1) [21, 23]. For a comprehensive listing of recurring regions of DNA copy number alteration in childhood ALL, the reader is referred to the Supplementary Materials of refs [21, 34].

An important observation was that the nature and frequency of individual lesions varied significantly between B-ALL subtypes. Notably, $M L L$-rearranged leukemias harbor few additional genetic alterations, consistent with the notion that $M L L$-rearrangement may be sufficient to induce leukemia [35]. In contrast, ETV6-RUNXI (TEL-AML1) and BCR-ABL1 rearranged leukemias harbor 6-8 additional copy number alterations per case and may present years after the acquisition of the founding translocation, indicating that these additional genetic alterations are required to induce the full leukemic phenotype.

\section{Genetic alterations perturbing lymphoid development in B-progenitor ALL}

A key observation is that over two-thirds of B-progenitor ALL cases have genetic alterations that disrupt the normal process of lymphoid maturation [21, 34]. The development of the Blymphoid lineage from hematopoietic stem cells is controlled by multiple transcription factors that control B lymphoid lineage commitment, the repression of alternate lineage fates, and lymphoid maturation. Common targets of alteration are PAX5 (paired box 5), IKZF1 (IKAROS), EBF1 (early B cell factor 1) and LEF1 (lymphoid enhancer factor 1). These genetic alterations are commonly heterozygous and include focal and broad deletions, sequence mutations, and translocations. The most common alteration is PAX5 (30\% of cases), which is seen in multiple subtypes of B-ALL (Figure 2). IKZFI alteration is less common, is more commonly deletion than sequence mutation, and is a hallmark of multiple subtypes of high-risk ALL (see below) [22, 36, 37]. Most B-ALL cases exhibit a block in maturation at the pro- to pre- $\mathrm{B}$ cell stage of maturation, and these transcriptional regulators control differentiation from the HSC to these early stages of B-cell maturation, suggesting that these genetic alterations directly contribute to the block in maturation that is a hallmark of B-ALL. Consistent with this, emerging studies using knockout mouse models to examine the role of Pax5 and Ikzfl loss in leukemogenesis have shown that loss of these alleles accelerates the onset of ALL [38-41].

\section{Genetic alterations in high-risk ALL}

A notable finding from these genomic analyses is that alterations of PAX5 are common in ALL but do not influence treatment outcome [34], whereas alterations of IKZFI are less common but strongly associated with poor outcome in multiple distinct subtypes of highrisk ALL_BCR-ABL1-positive lymphoid leukemia $[22,36]$ and a novel subtype of "BCRABL1-like" lymphoid leukemia [34, 42].

BCR-ABL1, encoded by the Philadelphia chromosome, is a hallmark of chronic myeloid leukemia (CML) and acute lymphoblastic leukemia. These two diseases differ markedly in phenotype and responsiveness to therapy. Genomic profiling of both diseases, including sequential CML samples obtained at diagnosis, remission, and transition to accelerated phase and myeloid or lymphoid blast crisis demonstrated that loss-of-function or dominant negative alterations of IKZFI (IKAROS) are a hallmark of BCR-ABL1 lymphoid leukemia, 
including de novo ALL and CML at the transition to lymphoid blast crisis [22, 43]. Alteration of $I K Z F 1$ is also associated with poor outcome in $B C R-A B L 1$ positive adult ALL [37]. Accordingly, loss of IKZFI or expression of dominant negative IKAROS isoforms (particularly the IK6 isoform that lacks coding exons 3 through 6, and the N-terminal zinc fingers) results in accelerated onset of ALL in experimental models [41] and resistance to tyrosine kinase inhibitors, providing a plausible mechanism as to why the responsiveness to treatment of $B C R-A B L 1$ ALL is considerably inferior to that of chronic phase ALL. Ongoing studies are using genome wide analysis of sequence variation to address unanswered questions in this disease, including the often striking differences in outcome between childhood and adult BCR-ABL1 positive ALL, genetic alterations that may drive high leukocyte counts (and poor outcome) and the nature of genetic alterations in IKZFI-wild type BCR-ABL1 ALL.

\section{IKZF1 and BCR-ABL1-like ALL}

Several studies have shown that alteration of $I K Z F I$ is also associated with poor outcome in $B C R-A B L 1$-negative childhood ALL [34, 44-46]. The association between IKZFI alterations is striking, in some studies tripling the risk of relapse. Moreover, the association of $I K Z F I$ status and outcome is commonly independent of commonly used risk stratification features such as age, sex, white cell count, and levels of minimal residual disease, suggesting that testing for IKZFI status at the time of diagnosis is warranted. This is being explored in prospective trials, but it should be emphasized that the variety of genetic alteration involving $I K Z F I$ requires the use of multiple, complementary genetic approaches, including tests that detect the (commonly focal) deletions, as well as the less common sequence variations.

These IKZF1-mutated, high-risk cases commonly lack known recurring chromosomal rearrangements, but have a gene expression profile that is remarkably similar to that of $B C R$ $A B L 1$-positive ALL $[34,42]$. This suggests that IKZFI alteration may directly influence the leukemic transcriptome, or that these cases harbor additional genetic alterations that results in activated kinase signaling analogous to that induced by expression of $B C R-A B L 1$. Both hypotheses are true. IKZFI-altered ALL cases exhibit enrichment for hematopoietic stem cell genes, consistent with the notion that loss of IKAROS activity results in maturational arrest. In addition, $B C R-A B L 1$-like ALL cases commonly harbor novel genetic alterations dysregulating cytokine receptor and tyrosine kinase signaling.

Up to $50 \%$ of $B C R$ - $A B L 1$-like ALL cases harbor rearrangements that dysregulate expression of $C R L F 2$ (encoding cytokine receptor like factor 2, or thymic stromal lymphopoietin; Figure 3) [47-49]. CRLF2 is located in the pseudoautosomal region 1 (PAR1) of $\mathrm{Xp} / \mathrm{Yp}$, and the alterations include juxtaposition of $\mathrm{Xp} / \mathrm{Yp}$ into the immunoglobulin heavy chain locus at 14q32, resulting in IGH@-CRLF2 rearrangement [48], or a focal deletion of PAR1 that juxtaposes the regulatory elements of the purinergic receptor gene $P 2 R Y 8$ to $C R L F 2$, and a chimeric P2RY8-CRLF2 fusion [47]. Less commonly, a missense mutation in exon 6 of CRLF2, F232C, results in constitutive CRLF2 dimerization [49]. All three events result in overexpression of full length CRLF2 on the cell surface of leukemic cells harboring the genetic alterations [47]. The PAR1 deletion is more common than the IGH@-CRLF2 rearrangement, although this is somewhat cohort dependent. CRLF2 rearrangement is particularly common in Down syndrome-associated ALL and is present in approximately $55 \%$ of these cases.

CRLF2 is known to have a role in T-lymphoid and dendritic cell development [50-52] and the pathogenesis of atopic disorders, but at present the role of CRLF2 in B-lymphoid neoplasms is relatively poorly understood. The downstream mediators of CRLF2 signaling 
are incompletely characterized but are likely to involve the Janus kinase family, and up to $50 \%$ of $C R L F 2$ rearranged ALL cases harbor concomitant activating mutations in JAK1 or JAK2 [47, 53, 54]. These are most commonly at or near R683 in the pseudokinase domain of JAK2 (although notably never at JAK2 V617 which is commonly mutated in myeloproliferative neoplasms, MPNs) [55], but are located throughout the kinase and pseudokinase domains of JAK1 and JAK2, most commonly at R683 in the pseudokinase domain of JAK2. The mutations in the pseudokinase domain of JAK2 are predicted to impair the negative regulatory effects of this domain on the catalytic activity of the kinase domain $[56,57]$. The kinase domain mutations are predicted to impair interaction of the kinase domain with its substrates (including the pseudokinase domain) or are located in the catalytic site and are predicted to be directly activating [57]. In vitro studies indicate that, in contrast to the V617F mutations in MPNs that may alone transform hematopoietic cells, the JAK1/2 mutations observed in ALL usually require concomitant expression of CRLF2 in order to induce transformation, and moreover that mutant JAK2 and CRLF2 physically associate.

\section{Novel kinase-activating alterations in BCR-ABL-like ALL}

At least $50 \%$ of BCR-ABL1-like ALL cases lack known genetic alterations resulting in aberrant cytokine receptor and kinase signaling, including those involving $C R L F 2$ and Janus kinases. Perhaps surprisingly, sequencing of the tyrosine kinome of $B C R-A B L 1$-like ALL cases has failed to identify any novel kinase-activating sequence mutations apart from those involving the Janus kinases [58]. In contrast, transcriptome and whole genome sequencing of a small cohort of $B C R$ - $A B L 1$-like ALL cases has been highly revealing and has identified novel rearrangements, sequence mutations, and DNA copy number alterations activating tyrosine kinase signaling in the majority of BCR-ABL1-like cases [59]. In this approach, sequencing of cDNA libraries prepared from leukemic cells is performed using second generation sequencers (eg, the Illumina GAIIx) and the paired reads from each cDNA molecule sequenced are mapped to the reference genome in order to identify chimeric cDNA sequences using a variety of bioinformatics algorithms [60, 61]. In a study of 12 $B C R$ - $A B L 1$-like cases, transcriptome sequencing identified sequencing identified rearrangements of $A B L 1, J A K 2, P D G F R B$ and EPOR in 7 of 9 cases that lacked known rearrangements (the other three cases were known to have $C R L F 2$ rearrangements) [59]. These rearrangements included the NUP214-ABL1 rearrangement previously identified in Tlineage ALL [62], BCR-JAK2, STRN3-JAK2, and EBF1-PDGFRB. Notably, several of these individual rearrangements and genes are also rearranged in myeloproliferative disorders [63-67], but have not previously been known to be rearranged in B-progenitor ALL. All BCR-ABL1-like B-ALL cases with these fusions harbor concomitant alterations of IKZF1, commonly the dominant negative IK6 deletion, suggesting that these two alterations drive proliferation of lymphoid cells as well as arresting lymphoid development, contributing to expression of an aggressive B-lymphoid malignancy. Several observations illustrate the complexity of the alterations that may result in aberrant kinase signaling. One case was predicted by RNA-seq to have a rearrangement of IGH@ to the erythropoietin receptor $(E P O R)$ which has previously reported to be associated with a reciprocal $t(14 ; 19)$ translocation [68]. Fluorescence in situ hybridization for this rearrangement was negative, and careful mapping and manual inspection of RNA-seq read data indicated that this rearrangement was from a focal $7 \mathrm{~kb}$ insertion of most of the EPOR locus into IGH@ adjacent to the promoter regions of this gene. An additional case lacked a putative fusion on RNA-seq analysis, but whole genome sequencing identified an activating mutation in the transmembrane domain of the interleukin-7 receptor alpha chain, which has recently been identified in both B- and T-ALL ([69] and Zhang et al, submitted). This case also harbored a concomitant focal inactivating deletion of $S H 2 B 3$, encoding $\mathrm{LNK}$, a negative regulator of JAK2 signaling [70], which is also mutated in JAK2 V617F-negative MPNs [71-73] and 
whose inactivation accelerates the onset of myeloproliferative disease in murine models of MPN [74].

Each of these alterations is predicted to activate the tyrosine kinase domain of the rearranged gene or result in constitutive cytokine receptor signaling (eg, EPOR and $I L 7 R$ ). Existing experimental data support this notion. Murine cytokine-dependent hematopoietic $\mathrm{Ba} / \mathrm{F} 3$ cells expressing NUP214-ABL1 or EBF1-PDGFRB are transformed to factor-independent cell growth and exhibit activation of downstream signaling pathways, which is also evident on flow cytometric analysis of primary leukemic cells obtained from patients harboring these alterations. Moreover, this transformation and signaling is attenuated by low concentrations of currently available tyrosine kinase inhibitors such as imatinib and dasatinib, suggesting that these will be therapeutically useful in these patients.

Thus, collectively, these data have identified two subtypes of high-risk BCR-ABL-like ALL; one with CRLF2 rearrangement and JAK1/2 mutation, and a second with a diverse array of rearrangements, sequence and structural mutations constitutively activating kinase signaling. While $C R L F 2$ rearrangements may be readily detected by genetic or flow cytometric techniques, detection of a diverse array of kinase gene rearrangements - not all of which have been currently identified and many of which are cytogenetically cryptic-poses major challenges. However, our existing data suggest leukemic cells harboring these alterations may be identified by focused gene expression profiling or flow cytometric analysis of primary leukemic cells (eg, for phosphorylated CRKL or tyrosine), suggesting that these may be useful diagnostic approaches. A challenge for the future is defining the nature and frequency of these alterations in adolescents and adults with ALL, for whom the outcome of therapy is often poor. These studies are ongoing.

\section{Other novel subgroups of B-progenitor ALL}

Cytogenetic analyses identify recurring chromosomal alterations in approximately $75 \%$ of childhood ALL; until the advent of microarray genome-wide profiling, the underlying genetic alterations of the remaining $25 \%$ were unknown. The majority of these cases may now be accounted for by the genetic alterations described above: CRLF2 rearrangement ( $5 \%-7 \%$ of cases), the heterogeneous alterations in the remaining BCR-ABL1-like cases $(5 \%-7 \%)$, as well as several additional diagnostic groups, including intrachromosomal amplification of chromosome 21 and alterations of $E R G$ (see below). It is likely that several additional groups defined by recurring chromosomal alterations, submicroscopic structural alterations, and sequence variations will be identified, especially with ongoing studies of ALL in older individuals, in which the recurring alterations common in childhood ALL are uncommon or absent (eg, hyperdiploidy and ETV6-RUNX1).

\section{Intrachromosomal amplification of chromosome 21}

Intrachromosomal amplification of chromosome 21 (iAMP21) defines up to $2 \%$ of B-ALL cases $[75,76]$. The region of amplification is typically large but variable, however, but always includes gain of at least three copies of RUNX1, commonly with accompanying deletion of the subtelomeric regions of chromosome 21. iAMP21 is characterized by commonly complex patterns of chromosomal rearrangement suggestive of breakage-fusionbridge cycle $[77,78]$. iAMP21 frequently occurs in older children or adolescents and is associated with a distinct gene expression profile [79] and poor outcome in the UK childhood ALL trials [80, 81]. 


\section{ERG deletions in ALL}

Focal deletions of $E R G$ occur exclusively in cases lacking known chromosomal rearrangements and are a hallmark of a novel subtype of B-ALL with a distinct gene expression profile. The $E R G$ deletions involve an internal subset of exons resulting in loss of the central inhibitory and pointed domains, and expression of an aberrant C-terminal ERG fragment that retains the ETS and transactivation domains, and functions as a competitive inhibitor of wild-type ERG [82]. These findings are in contrast to the rearrangements of $E R G$ observed in carcinoma of the prostate, which result in in marked overexpression of the most of the ERG protein [83].

\section{Genetic alterations in relapsed ALL}

The studies described above have focused primarily on genetic alterations identified by profiling of the "bulk" leukemic sample obtained at relapse. There is now burgeoning evidence that many newly diagnosed ALL cases are in fact composites of multiple subclones that harbor distinct genetic alterations (including both copy number alterations and sequence mutations) that may influence treatment responsiveness and the risk of relapse.

Evolution or alterations in cytogenetic abnormalities from diagnosis to relapse in ALL has been recognized for many years [84], and several studies have performed limited candidate gene sequencing studies and shown that relapsed ALL samples may acquire sequence mutations (eg, NRAS, TP53) not present in the bulk diagnosis leukemic clone [85-87]. To look more broadly at the patterns of genetic alteration, several groups including our own performed genome-wide analysis of DNA copy number alterations in cohorts of matched diagnosis and relapsed ALL samples and demonstrated that in the majority of cases, the diagnosis and relapse samples share a common pre-diagnosis or "ancestral" clonal origin, but exhibit differences in the nature of genetic alterations [88-91]. In less than $10 \%$ of cases is a completely distinct leukemia identified bearing no similarity whatsoever to the diagnosis clone, although this frequency may be higher in certain ALL subgroups, such as laterelapsing T-ALL [92]. Similarly, relatively few samples are genetically identical at diagnosis and relapse. In contrast, approximately one third of cases show the acquisition of new genetic alterations in addition to those seen at diagnosis (ie, simple clonal evolution). In over half of cases, the pattern is more complex, with sharing of some lesions between diagnosis and relapse, loss of some lesions present at diagnosis, and the acquisition of new genetic alterations. In the majority of cases, "new" genetic alterations first detected at relapse may be detected at diagnosis using sensitive molecular methods, indicating that the relapse clones are present at low levels at diagnosis. Notably, many of the new lesions emerging at relapse are associated with aggressive disease or treatment failure, including $I K Z F I$ and $C D K N 2 A / B$ deletions.

Recent studies have coupled these genomic analyses with xenotransplantation studies of diagnosis and relapsed leukemia cells in mice, in which complementary genomic profiling of the xenograft samples is compared to primary leukemic samples. These studies have confirmed the observations made from the comparative genomic profiling of diagnosis and relapse samples. Specifically, diagnosis samples are comprised of multiple subclones that selectively engraft different recipient mice transplanted with the same primary tumor; that the clones that engraft mice may be genetically identical to the clones that emerge in patients at the time of relapse, and that specific genetic alterations (eg, deletion of CDKN2A/ $C D K N 2 B$ is associated with aggressive growth in mice) [93-95].

A logical extension of these studies is to perform genome-wide analysis of sequence variation in diagnosis and relapsed leukemia samples. To that end we performed extensive Sanger resequencing of 300 genes in a cohort of 23 matched diagnosis-relapse samples [96]. 
The findings from this study mirrored those of the SNP microarray analysis of DNA copy number alterations, namely that matched diagnosis and relapse samples share some mutations, but are dissimilar at other loci. A striking findings was that 19 percent of relapsed ALL samples harbor loss-of-function mutations (either deletions or sequence mutations) of $C R E B B P$, encoding CREB-binding protein or CBP. CREBBP is a large protein with multiple roles including transcriptional coactivation and acetylation of histone and nonhistone targets [97-99]. Rearrangements of $C R E B B P$ and the homologous gene EP300 (p300) are rare events in acute leukemia [100], and focal deletions of CREBBP are observed (uncommonly) in B-ALL, but sequence mutations of this gene in cancer have not previously been reported.

The sequence mutations of CREBBP observed in relapsed ALL included missense, nonsense, and frameshift mutations throughout the gene, with clustering of missense mutations in the histone acetyltransferase (HAT) domain. CREBPP is also mutated in the inherited developmental disorder Rubinstein-Taybi syndrome [101], and notably, a HAT domain mutation observed as a somatic event in relapsed ALL, Q1500P is also observed as an inherited mutation in Rubinstein-Taybi syndrome. Several lines of evidence indicate that the mutations in CREBBP are deleterious and are likely to influence treatment responsiveness in ALL. In contrast to other common targets of sequence mutation (eg, $N R A S, K R A S, N F 1$ ), which when present at diagnosis may no longer be evident at relapse, the $C R E B B P$ mutations are (1) preserved at relapse when present at diagnosis; (2) acquired at relapse but present in minor subclones at diagnosis; or (3) reduplicated to homozygosity at relapse when heterozygous at diagnosis. Structural modeling of the HAT domain mutations (using the crystal structure of the highly homologous EP300 HAT domain) shows that the missense mutations are likely to interfere with binding to the acetylation substrates of CREBBP. Moreover, introduction of the mutations variable attenuates acetylation of histone $\mathrm{H} 3$ lysine 18 (H3K18, a critical CREBBP acetylation substrate) in $\mathrm{Crebbp}^{-1-} \mathrm{Ep} 300^{-/-}$murine embryonic fibroblasts. Moreover, CREBBP is an important mediator of the transcriptional response to glucocorticoids, which are widely used in therapy of ALL, and the mutations directly impair the transcriptional response to glucorticoids. Finally, T-ALL cell lines harboring CREBBP mutations that are resistant to dexamethasone are highly sensitive to the histone deacetylase inhibitor vorinostat. Together, these data suggest that CREBBP alterations directly influence the response of leukemic cells to chemotherapy, and that modulation of CREBBP activity, such as with histone deacetylase inhibitors, may represent an important therapeutic approach in high-risk and relapsed ALL [102]. Several caveats, should, however be stated. While the in vitro evidence for a role of CREBPP mutations adversely impairing corticosteroid responses is compelling, these data are derived from non-leukemic cells (murine embryonic fibroblasts) and as CREBBP exerts pleiotropic effects, the exact manner in which CREBBP alterations influence leukemogenesis and responsiveness to therapy remains to be defined. Indeed, as the sequence mutation in CREBBP are located in different CREBBP domains (that interact with different transcription factors and partner genes), it is possible that different mutations have quite distinct effects. Moreover, contemporaneous work profiling genetic alterations in nonHodgkin lymphoma identified inactivating mutations of CREBBP and EP300 in over one third of diffuse large-cell non-Hodgkin lymphoma (NHL) and follicular lymphoma in samples obtained at diagnosis $[103,104]$. CREBBP may directly acetylate BCL6, which is of key importance in the pathogenesis of NHL, and thus it is likely that the alterations of CREBBP may exert distinct effects in lymphoma pathogenesis and responsiveness to treatment in ALL (in which mutations in these genes are rare at diagnosis, in contrast to NHL). 


\section{Future directions}

The studies described above have provided clear evidence of the power of genome-wide profiling approaches to identify genes and pathways of central importance in establishment of the leukemic clone, and also in responsiveness to therapy. It is likely that much remains to be learned. These studies have primarily used microarray-based technology and candidate gene sequencing that provide only a sampling of the leukemic genome. Efforts are now well advanced to perform whole genome-sequencing of ALL, which will provide a comprehensive view of the landscape of genetic alterations in this disease, which has proven so informative in acute myeloid leukemia $[6,105,106]$. In addition to providing a catalog of structural and sequence variants affecting coding genes, these efforts will also allow detailed examination of non-coding genomic variation, which is likely important but at present relatively unexplored. It is also emphasized that many of the insights described above have only been possible with the detailed examination of large patient cohorts with comprehensive clinical data, and by the systematic integration of multiple modalities of genomic data including structural variants, sequence variation and gene expression. This will remain important with advances into the "whole-genome" age.

From the clinical perspective, the question remains as to how best integrate these findings into patient care. While there is great interest in performing microarray profiling and indeed, whole genome sequencing on patients at the time of diagnosis, a note of caution is warranted. We are still determining the functional and clinical relevance of many of the recurring lesions identified by these approaches, and indeed for next generation sequencing, still optimizing analytical approaches to sensitively and robustly identify all key genetic alterations [107]. Moreover, as the studies from transcriptomic sequencing of BCR-ABL1like ALL attest, the genomic alterations driving otherwise homogenous subtypes of acute leukemia may be complex and polygenic and entail expensive, multimodal genomic analyses that are poorly suited to rapid clinical testing. Thus, the translation of findings from next generation sequencing to more conventional clinical tests such as flow cytometry, candidate gene sequencing, or focused gene expression profiling are likely to remain valuable approaches. Nonetheless, the genomic analysis of ALL is at a critical and tremendously exciting time, and the next few years are likely to lay bare the genetic aberrations of this disease and provide critical insights for future mechanistic analyses and clinical advances.

\section{Acknowledgments}

The author thanks colleagues at St Jude Children's Research Hospital, the Children's Oncology Group, the National Cancer Institute, and the Institute of Medical and Veterinary Science, Adelaide, Australi, who have contributed to these studies. The work described herein is supported by the American and Lebanese Syrian Associated Charities of St Jude Children's Research Hospital, the Haematology Society of Australia and New Zealand, and grants from the National Cancer Institute and the TARGET (Therapeutically Applicable Research to Generate Effective Treatments) Initiative of the NCI. The author is a Pew Scholar in the Biomedical Sciences, and a St. Baldrick's Scholar.

\section{References}

1. Pui CH, Howard SC. Current management and challenges of malignant disease in the CNS in paediatric leukaemia. Lancet Oncol. 2008; 9:257-68. [PubMed: 18308251]

2. Advani AS, Hunger SP, Burnett AK. Acute leukemia in adolescents and young adults. Semin Oncol. 2009; 36:213-26. [PubMed: 19460579]

3. Pui CH, Carroll WL, Meshinchi S, Arceci RJ. Biology, risk stratification, and therapy of pediatric acute leukemias: an update. J Clin Oncol. 2011; 29:551-65. [PubMed: 21220611]

4. Mullighan CG, Downing JR. Genome-wide profiling of genetic alterations in acute lymphoblastic leukemia: recent insights and future directions. Leukemia. 2009; 23:1209-18. [PubMed: 19242497] 
5. Beroukhim R, Mermel CH, Porter D, Wei G, Raychaudhuri S, Donovan J, et al. The landscape of somatic copy-number alteration across human cancers. Nature. 2010; 463:899-905. [PubMed: 20164920]

6. Ley TJ, Mardis ER, Ding L, Fulton B, McLellan MD, Chen K, et al. DNA sequencing of a cytogenetically normal acute myeloid leukaemia genome. Nature. 2008; 456:66-72. [PubMed: 18987736]

7. Raimondi, SC. Cytogenetics of acute leukemias. In: Pui, CH., editor. Childhood Leukemias. 2. Cambridge: Cambridge University Press; 2006. p. 235-71.

8. Harrison CJ. Cytogenetics of paediatric and adolescent acute lymphoblastic leukaemia. Br J Haematol. 2009; 144:147-56. [PubMed: 19006567]

9. Harrison CJ, Moorman AV, Broadfield ZJ, Cheung KL, Harris RL, Reza Jalali G, et al. Three distinct subgroups of hypodiploidy in acute lymphoblastic leukaemia. Br J Haematol. 2004; 125:552-9. [PubMed: 15147369]

10. Heerema NA, Nachman JB, Sather HN, Sensel MG, Lee MK, Hutchinson R, et al. Hypodiploidy with less than 45 chromosomes confers adverse risk in childhood acute lymphoblastic leukemia: a report from the children's cancer group. Blood. 1999; 94:4036-45. [PubMed: 10590047]

11. Nachman JB, Heerema NA, Sather H, Camitta B, Forestier E, Harrison CJ, et al. Outcome of treatment in children with hypodiploid acute lymphoblastic leukemia. Blood. 2007; 110:1112-5. [PubMed: 17473063]

12. Pui CH, Williams DL, Raimondi SC, Rivera GK, Look AT, Dodge RK, et al. Hypodiploidy is associated with a poor prognosis in childhood acute lymphoblastic leukemia. Blood. 1987; 70:247-53. [PubMed: 3474042]

13. Raimondi SC, Zhou Y, Mathew S, Shurtleff SA, Sandlund JT, Rivera GK, et al. Reassessment of the prognostic significance of hypodiploidy in pediatric patients with acute lymphoblastic leukemia. Cancer. 2003; 98:2715-22. [PubMed: 14669294]

14. Romana SP, Mauchauffe M, Le Coniat M, Chumakov I, Le Paslier D, Berger R, et al. The t(12;21) of acute lymphoblastic leukemia results in a tel-AML1 gene fusion. Blood. 1995; 85:3662-70. [PubMed: 7780150]

15. Golub TR, Barker GF, Bohlander SK, Hiebert SW, Ward DC, Bray-Ward P, et al. Fusion of the TEL gene on 12p13 to the AML1 gene on 21q22 in acute lymphoblastic leukemia. Proc Natl Acad Sci U S A. 1995; 92:4917-21. [PubMed: 7761424]

16. Aifantis I, Raetz E, Buonamici S. Molecular pathogenesis of T-cell leukaemia and lymphoma. Nat Rev Immunol. 2008; 8:380-90. [PubMed: 18421304]

17. Meijerink JP. Genetic rearrangements in relation to immunophenotype and outcome in T-cell acute lymphoblastic leukaemia. Best Pract Res Clin Haematol. 2010; 23:307-18. [PubMed: 21112032]

18. Graux C, Cools J, Michaux L, Vandenberghe P, Hagemeijer A. Cytogenetics and molecular genetics of T-cell acute lymphoblastic leukemia: from thymocyte to lymphoblast. Leukemia. 2006; 20:1496-510. [PubMed: 16826225]

19. Okuda T, Shurtleff SA, Valentine MB, Raimondi SC, Head DR, Behm F, et al. Frequent deletion of p16INK4a/MTS1 and p15INK4b/MTS2 in pediatric acute lymphoblastic leukemia. Blood. 1995; 85:2321-30. [PubMed: 7727766]

20. Weng AP, Ferrando AA, Lee W, Morris JPt, Silverman LB, Sanchez-Irizarry C, et al. Activating mutations of NOTCH1 in human T cell acute lymphoblastic leukemia. Science. 2004; 306:269-71. [PubMed: 15472075]

21. Mullighan CG, Goorha S, Radtke I, Miller CB, Coustan-Smith E, Dalton JD, et al. Genome-wide analysis of genetic alterations in acute lymphoblastic leukaemia. Nature. 2007; 446:758-64. [PubMed: 17344859]

22. Mullighan CG, Miller CB, Radtke I, Phillips LA, Dalton J, Ma J, et al. BCR-ABL1 lymphoblastic leukaemia is characterized by the deletion of Ikaros. Nature. 2008; 453:110-4. [PubMed: 18408710]

23. Kuiper RP, Schoenmakers EF, van Reijmersdal SV, Hehir-Kwa JY, van Kessel AG, van Leeuwen FN, et al. High-resolution genomic profiling of childhood ALL reveals novel recurrent genetic lesions affecting pathways involved in lymphocyte differentiation and cell cycle progression. Leukemia. 2007; 21:1258-66. [PubMed: 17443227] 
24. Kawamata N, Ogawa S, Zimmermann M, Kato M, Sanada M, Hemminki K, et al. Molecular allelokaryotyping of pediatric acute lymphoblastic leukemias by high-resolution single nucleotide polymorphism oligonucleotide genomic microarray. Blood. 2008; 111:776-84. [PubMed: 17890455]

25. Van Vlierberghe P, Homminga I, Zuurbier L, Gladdines-Buijs J, van Wering ER, Horstmann M, et al. Cooperative genetic defects in TLX3 rearranged pediatric T-ALL. Leukemia. 2008; 22:762-70. [PubMed: 18185524]

26. van Vlierberghe P, Meijerink JP, Lee C, Ferrando AA, Look AT, van Wering ER, et al. A new recurrent 9q34 duplication in pediatric T-cell acute lymphoblastic leukemia. Leukemia. 2006; 20:1245-53. [PubMed: 16673019]

27. Parker H, An Q, Barber K, Case M, Davies T, Konn Z, et al. The complex genomic profile of ETV6-RUNX1 positive acute lymphoblastic leukemia highlights a recurrent deletion of TBL1XR1. Genes Chromosomes Cancer. 2008; 47:1118-25. [PubMed: 18767146]

28. Golub TR, Slonim DK, Tamayo P, Huard C, Gaasenbeek M, Mesirov JP, et al. Molecular classification of cancer: class discovery and class prediction by gene expression monitoring. Science. 1999; 286:531-7. [PubMed: 10521349]

29. Ross ME, Zhou X, Song G, Shurtleff SA, Girtman K, Williams WK, et al. Classification of pediatric acute lymphoblastic leukemia by gene expression profiling. Blood. 2003; 102:2951-9. [PubMed: 12730115]

30. Yeoh EJ, Ross ME, Shurtleff SA, Williams WK, Patel D, Mahfouz R, et al. Classification, subtype discovery, and prediction of outcome in pediatric acute lymphoblastic leukemia by gene expression profiling. Cancer Cell. 2002; 1:133-43. [PubMed: 12086872]

31. Mullighan CG. Single nucleotide polymorphism microarray analysis of genetic alterations in cancer. Methods Mol Biol. 2011; 730:235-58. [PubMed: 21431646]

32. Heinrichs S, Li C, Look AT. SNP array analysis in hematologic malignancies: avoiding false discoveries. Blood. 2010; 115:4157-61. [PubMed: 20304806]

33. Paulsson K, Cazier JB, Macdougall F, Stevens J, Stasevich I, Vrcelj N, et al. Microdeletions are a general feature of adult and adolescent acute lymphoblastic leukemia: Unexpected similarities with pediatric disease. Proc Natl Acad Sci U S A. 2008; 105:6708-13. [PubMed: 18458336]

34. Mullighan CG, Su X, Zhang J, Radtke I, Phillips LA, Miller CB, et al. Deletion of IKZF1 and prognosis in acute lymphoblastic leukemia. N Engl J Med. 2009; 360:470-80. [PubMed: 19129520]

35. Bardini M, Spinelli R, Bungaro S, Mangano E, Corral L, Cifola I, et al. DNA copy-number abnormalities do not occur in infant ALL with $\mathrm{t}(4 ; 11) /$ MLL-AF4. Leukemia. 2010; 24:169-76. [PubMed: 19907438]

36. Iacobucci I, Storlazzi CT, Cilloni D, Lonetti A, Ottaviani E, Soverini S, et al. Identification and molecular characterization of recurrent genomic deletions on $7 \mathrm{p} 12$ in the IKZF1 gene in a large cohort of BCR-ABL1-positive acute lymphoblastic leukemia patients: on behalf of Gruppo Italiano Malattie Ematologiche dell'Adulto Acute Leukemia Working Party (GIMEMA AL WP). Blood. 2009; 114:2159-67. [PubMed: 19589926]

37. Martinelli G, Iacobucci I, Storlazzi CT, Vignetti M, Paoloni F, Cilloni D, et al. IKZF1 (Ikaros) deletions in BCR-ABL1-positive acute lymphoblastic leukemia are associated with short diseasefree survival and high rate of cumulative incidence of relapse: a GIMEMA AL WP report. J Clin Oncol. 2009; 27:5202-7. [PubMed: 19770381]

38. Virely C, Moulin S, Cobaleda C, Lasgi C, Alberdi A, Soulier J, et al. Haploinsufficiency of the IKZF1 (IKAROS) tumor suppressor gene cooperates with BCR-ABL in a transgenic model of acute lymphoblastic leukemia. Leukemia. 2010; 24:1200-4. [PubMed: 20393504]

39. Heltemes-Harris LM, Willette MJ, Ramsey LB, Qiu YH, Neeley ES, Zhang N, et al. Ebf1 or Pax5 haploinsufficiency synergizes with STAT5 activation to initiate acute lymphoblastic leukemia. J Exp Med. 2011; 208:1135-49. [PubMed: 21606506]

40. Dang J, Mullighan CG, Phillips LA, Mehta P, Downing JR. Retroviral and chemical mutagenesis identifies Pax 5 as a tumor suppressor in B-progenitor acute lymphoblastic leukemia. Blood (ASH Annual Meeting Abstracts). 2008; 112:1789. 
41. Collins-Underwood JR, Boulos N, Payne-Turner D, Chen S-C, Williams R, Mullighan C. The role of dominant-negative IKAROS mutations in the pathogenesis and treatment responsiveness of BCR-ABL1 positive acute lymphoblastic leukemia. Blood (ASH Annual Meeting Abstracts). 2010; 116:540.

42. Den Boer ML, van Slegtenhorst M, De Menezes RX, Cheok MH, Buijs-Gladdines JG, Peters ST, et al. A subtype of childhood acute lymphoblastic leukaemia with poor treatment outcome: a genome-wide classification study. Lancet Oncol. 2009; 10:125-34. [PubMed: 19138562]

43. Tefferi A. Novel mutations and their functional and clinical relevance in myeloproliferative neoplasms: JAK2, MPL, TET2, ASXL1, CBL, IDH and IKZF1. Leukemia. 2010; 24:1128-38. [PubMed: 20428194]

44. Yang YL, Hung CC, Chen JS, Lin KH, Jou ST, Hsiao CC, et al. IKZF1 deletions predict a poor prognosis in children with B-cell progenitor acute lymphoblastic leukemia: A multicenter analysis in Taiwan. Cancer Sci. 2011

45. Kuiper RP, Waanders E, van der Velden VH, van Reijmersdal SV, Venkatachalam R, Scheijen B, et al. IKZF1 deletions predict relapse in uniformly treated pediatric precursor B-ALL. Leukemia. 2010; 24:1258-64. [PubMed: 20445578]

46. Waanders E, van der Velden VH, van der Schoot CE, van Leeuwen FN, van Reijmersdal SV, de Haas V, et al. Integrated use of minimal residual disease classification and IKZF1 alteration status accurately predicts $79 \%$ of relapses in pediatric acute lymphoblastic leukemia. Leukemia. 2011; 25:254-8. [PubMed: 21102428]

47. Mullighan CG, Collins-Underwood JR, Phillips LA, Loudin MG, Liu W, Zhang J, et al. Rearrangement of CRLF2 in B-progenitor- and Down syndrome-associated acute lymphoblastic leukemia. Nat Genet. 2009; 41:1243-6. [PubMed: 19838194]

48. Harvey RC, Mullighan CG, Chen IM, Wharton W, Mikhail FM, Carroll AJ, et al. Rearrangement of CRLF2 is associated with mutation of JAK kinases, alteration of IKZF1, Hispanic/Latino ethnicity, and a poor outcome in pediatric B-progenitor acute lymphoblastic leukemia. Blood. 2010; 115:5312-21. [PubMed: 20139093]

49. Yoda A, Yoda Y, Chiaretti S, Bar-Natan M, Mani K, Rodig SJ, et al. Functional screening identifies CRLF2 in precursor B-cell acute lymphoblastic leukemia. Proc Natl Acad Sci U S A. 2010; 107:252-7. [PubMed: 20018760]

50. Liu YJ. Thymic stromal lymphopoietin: master switch for allergic inflammation. J Exp Med. 2006; 203:269-73. [PubMed: 16432252]

51. Zhou B, Comeau MR, De Smedt T, Liggitt HD, Dahl ME, Lewis DB, et al. Thymic stromal lymphopoietin as a key initiator of allergic airway inflammation in mice. Nat Immunol. 2005; 6:1047-53. [PubMed: 16142237]

52. Ziegler SF, Liu YJ. Thymic stromal lymphopoietin in normal and pathogenic T cell development and function. Nat Immunol. 2006; 7:709-14. [PubMed: 16785889]

53. Russell LJ, Capasso M, Vater I, Akasaka T, Bernard OA, Calasanz MJ, et al. Deregulated expression of cytokine receptor gene, CRLF2, is involved in lymphoid transformation in B-cell precursor acute lymphoblastic leukemia. Blood. 2009; 114:2688-98. [PubMed: 19641190]

54. Hertzberg L, Vendramini E, Ganmore I, Cazzaniga G, Schmitz M, Chalker J, et al. Down syndrome acute lymphoblastic leukemia: a highly heterogeneous disease in which aberrant expression of CRLF2 is associated with mutated JAK2: a report from the iBFM Study Group. Blood. 2010; 115:1006-17. [PubMed: 19965641]

55. Levine RL, Pardanani A, Tefferi A, Gilliland DG. Role of JAK2 in the pathogenesis and therapy of myeloproliferative disorders. Nat Rev Cancer. 2007; 7:673-83. [PubMed: 17721432]

56. Bercovich D, Ganmore I, Scott LM, Wainreb G, Birger Y, Elimelech A, et al. Mutations of JAK2 in acute lymphoblastic leukaemias associated with Down's syndrome. Lance. 2008; 372:1484-92.

57. Mullighan CG, Zhang J, Harvey RC, Collins-Underwood JR, Schulman BA, Phillips LA, et al. JAK mutations in high-risk childhood acute lymphoblastic leukemia. Proc Natl Acad Sci U S A. 2009; 106:9414-8. [PubMed: 19470474]

58. Zhang J, Mullighan C, Harvey R, Carroll WL, Chen I-ML, Devidas M, et al. Lack of somatic sequence mutations in protein tyrosine kinase genes other than the JAK kinase family in high risk B-precursor childhood acute lymphoblastic leukemia (ALL): Areport from the Children's 
Oncology Group (COG) High-Risk (HR) ALL TARGET Project. Blood (ASH Annual Meeting Abstracts). 2010; 116:2752.

59. Mullighan CG, Morin RD, Zhang J, Hirst M, Zhao Y, Yan C, et al. Next generation transcriptomic resequencing identifies novel genetic alterations in high-risk (HR) childhood acute lymphoblastic leukemia (ALL): A report from the Children's Oncology Group (COG) HR ALL TARGET Project. Blood. 2009; 114 abstract 704.

60. McPherson A, Hormozdiari F, Zayed A, Giuliany R, Ha G, Sun MGF, et al. deFuse: An algorithm for gene fusion discovery in tumor RNA-seq data. PLoS Comput Biol. 2011; 7:e1001138. [PubMed: 21625565]

61. Wang J, Mullighan CG, Easton J, Roberts S, Heatley SL, Ma J, et al. CREST maps somatic structural variation in cancer genomes with base-pair resolution. Nat Methods. 2011; 8:652-4. [PubMed: 21666668]

62. Graux C, Cools J, Melotte C, Quentmeier H, Ferrando A, Levine R, et al. Fusion of NUP214 to ABL1 on amplified episomes in T-cell acute lymphoblastic leukemia. Nat Genet. 2004; 36:10849. [PubMed: 15361874]

63. Cirmena G, Aliano S, Fugazza G, Bruzzone R, Garuti A, Bocciardi R, et al. A BCR-JAK2 fusion gene as the result of a $t(9 ; 22)(p 24 ; q 11)$ in a patient with acute myeloid leukemia. Cancer Genet Cytogenet. 2008; 183:105-8. [PubMed: 18503828]

64. Lane SW, Fairbairn DJ, McCarthy C, Nandini A, Perry-Keene J, Kennedy GA. Leukaemia cutis in atypical chronic myeloid leukaemia with a $\mathrm{t}(9 ; 22)$ (p24;q11. 2) leading to BCR-JAK2 fusion. Br J Haematol. 2008; 142:503. [PubMed: 18537978]

65. Cross NC, Reiter A. Tyrosine kinase fusion genes in chronic myeloproliferative diseases. Leukemia. 2002; 16:1207-12. [PubMed: 12094244]

66. Lierman E, Cools J. ETV6 and PDGFRB: a license to fuse. Haematologica. 2007; 92:145-7. [PubMed: 17296561]

67. Wlodarska I, Aventin A, Ingles-Esteve J, Falzetti D, Criel A, Cassiman JJ, et al. A new subtype of pre-B acute lymphoblastic leukemia with $\mathrm{t}(5 ; 12)(\mathrm{q} 31 \mathrm{q} 33 ; \mathrm{p} 12)$, molecularly and cytogenetically distinct from $\mathrm{t}(5 ; 12)$ in chronic myelomonocytic leukemia. Blood. 1997; 89:1716-22. [PubMed: 9057655]

68. Russell LJ, De Castro DG, Griffiths M, Telford N, Bernard O, Panzer-Grumayer R, et al. A novel translocation, t(14;19)(q32;p13), involving IGH@ and the cytokine receptor for erythropoietin. Leukemi. 2009; 23:614-7.

69. Shochat C, Tal N, Bandapalli OR, Palmi C, Ganmore I, te Kronnie G, et al. Gain-of-function mutations in interleukin-7 receptor-alpha (IL7R) in childhood acute lymphoblastic leukemias. J Exp Med. 2011; 208:901-8. [PubMed: 21536738]

70. Baran-Marszak F, Magdoud H, Desterke C, Alvarado A, Roger C, Harel S, et al. Expression level and differential JAK2-V617F-binding of the adaptor protein Lnk regulates JAK2-mediated signals in myeloproliferative neoplasms. Blood. 2010; 116:5961-71. [PubMed: 20870899]

71. Lasho TL, Pardanani A, Tefferi A. LNK mutations in JAK2 mutation-negative erythrocytosis. N Engl J Med. 2010; 363:1189-90. [PubMed: 20843259]

72. Pardanani A, Lasho T, Finke C, Oh ST, Gotlib J, Tefferi A. LNK mutation studies in blast-phase myeloproliferative neoplasms, and in chronic-phase disease with TET2, IDH, JAK2 or MPL mutations. Leukemia. 2010; 24:1713-8. [PubMed: 20724988]

73. Oh ST, Simonds EF, Jones C, Hale MB, Goltsev Y, Gibbs KD Jr, et al. Novel mutations in the inhibitory adaptor protein LNK drive JAK-STAT signaling in patients with myeloproliferative neoplasms. Blood. 2010; 116:988-92. [PubMed: 20404132]

74. Bersenev A, Wu C, Balcerek J, Jing J, Kundu M, Blobel GA, et al. Lnk constrains myeloproliferative diseases in mice. J Clin Invest. 2010; 120:2058-69. [PubMed: 20458146]

75. Harewood L, Robinson H, Harris R, Al-Obaidi MJ, Jalali GR, Martineau M, et al. Amplification of AML1 on a duplicated chromosome 21 in acute lymphoblastic leukemia: a study of 20 cases. Leukemia. 2003; 17:547-53. [PubMed: 12646943]

76. Soulier J, Trakhtenbrot L, Najfeld V, Lipton JM, Mathew S, Avet-Loiseau H, et al. Amplification of band q22 of chromosome 21, including AML1, in older children with acute lymphoblastic 
leukemia: an emerging molecular cytogenetic subgroup. Leukemia. 2003; 17:1679-82. [PubMed: 12886264]

77. Robinson HM, Harrison CJ, Moorman AV, Chudoba I, Strefford JC. Intrachromosomal amplification of chromosome 21 (iAMP21) may arise from a breakage-fusion-bridge cycle. Genes Chromosomes Cancer. 2007; 46:318-26. [PubMed: 17243167]

78. Sinclair PB, Parker H, An Q, Rand V, Ensor H, Harrison CJ, et al. Analysis of a breakpoint cluster reveals insight into the mechanism of intrachromosomal amplification in a lymphoid malignancy. Hum Mol Gen. 2011; 20:2591-602. [PubMed: 21487021]

79. Strefford JC, van Delft FW, Robinson HM, Worley H, Yiannikouris O, Selzer R, et al. Complex genomic alterations and gene expression in acute lymphoblastic leukemia with intrachromosomal amplification of chromosome 21. Proc Nat Acad Sci U S A. 2006; 103:8167-72.

80. Moorman AV, Richards SM, Robinson HM, Strefford JC, Gibson BE, Kinsey SE, et al. Prognosis of children with acute lymphoblastic leukemia (ALL) and intrachromosomal amplification of chromosome 21 (iAMP21). Blood. 2007; 109:2327-30. [PubMed: 17095619]

81. Moorman AV, Ensor HM, Richards SM, Chilton L, Schwab C, Kinsey SE, et al. Prognostic effect of chromosomal abnormalities in childhood B-cell precursor acute lymphoblastic leukaemia: results from the UK Medical Research Council ALL97/99 randomised trial. Lancet Oncol. 2010; 11:429-38. [PubMed: 20409752]

82. Mullighan CG, Miller CB, Su X, Radtke I, Dalton J, Song G, et al. ERG deletions define a novel subtype of B-progenitor acute lymphoblastic leukemia. Blood (ASH Annual Meeting Abstracts). 2007; 110:691.

83. Tomlins SA, Rhodes DR, Perner S, Dhanasekaran SM, Mehra R, Sun XW, et al. Recurrent fusion of TMPRSS2 and ETS transcription factor genes in prostate cancer. Science. 2005; 310:644-8. [PubMed: 16254181]

84. Raimondi SC, Pui CH, Head DR, Rivera GK, Behm FG. Cytogenetically different leukemic clones at relapse of childhood acute lymphoblastic leukemia. Blood. 1993; 82:576-80. [PubMed: 8329712]

85. Blau O, Avigad S, Stark B, Kodman Y, Luria D, Cohen IJ, et al. Exon 5 mutations in the p53 gene in relapsed childhood acute lymphoblastic leukemia. Leuk Res. 1997; 21:721-9. [PubMed: 9379679]

86. Gump J, McGavran L, Wei Q, Hunger SP. Analysis of TP53 mutations in relapsed childhood acute lymphoblastic leukemia. J Pediatr Hematol Oncol. 2001; 23:416-9. [PubMed: 11878574]

87. Terada N, Miyoshi J, Kawa-Ha K, Sasai H, Orita S, Yumura-Yagi K, et al. Alteration of N-ras gene mutation after relapse in acute lymphoblastic leukemia. Blood. 1990; 75:453-7. [PubMed: 1967219]

88. Mullighan CG, Phillips LA, Su X, Ma J, Miller CB, Shurtleff SA, et al. Genomic analysis of the clonal origins of relapsed acute lymphoblastic leukemia. Science. 2008; 322:1377-80. [PubMed: 19039135]

89. Yang JJ, Bhojwani D, Yang W, Cai X, Stocco G, Crews K, et al. Genome-wide copy number profiling reveals molecular evolution from diagnosis to relapse in childhood acute lymphoblastic leukemia. Blood. 2008; 112:4178-83. [PubMed: 18768390]

90. Kawamata N, Ogawa S, Seeger K, Kirschner-Schwabe R, Huynh T, Chen J, et al. Molecular allelokaryotyping of relapsed pediatric acute lymphoblastic leukemia. Int J Oncol. 2009; 34:160312. [PubMed: 19424578]

91. van Delft FW, Horsley S, Colman S, Anderson K, Bateman C, Kempski H, et al. Clonal origins of relapse in ETV6-RUNX1 acute lymphoblastic leukemia. Blood. 2011; 117:6247-54. [PubMed: 21482711]

92. Szczepanski T, van der Velden VH, Waanders E, Kuiper RP, Van Vlierberghe P, Gruhn B, et al. Late recurrence of childhood T-cell acute lymphoblastic leukemia frequently represents a second leukemia rather than a relapse: first evidence for genetic predisposition. J Clin Oncol. 2011; 29:1643-9. [PubMed: 21357790]

93. Notta F, Mullighan CG, Wang JC, Poeppl A, Doulatov S, Phillips LA, et al. Evolution of human BCR-ABL1 lymphoblastic leukaemia-initiating cells. Nature. 2011; 469:362-7. [PubMed: 21248843] 
94. Anderson K, Lutz C, van Delft FW, Bateman CM, Guo Y, Colman SM, et al. Genetic variegation of clonal architecture and propagating cells in leukaemia. Nature. 2011; 469:356-61. [PubMed: 21160474]

95. Clappier E, Gerby B, Sigaux F, Delord M, Touzri F, Hernandez L, et al. Clonal selection in xenografted human $\mathrm{T}$ cell acute lymphoblastic leukemia recapitulates gain of malignancy at relapse. J Exp Med. 2011; 208:653-61. [PubMed: 21464223]

96. Mullighan CG, Zhang J, Kasper LH, Lerach S, Payne-Turner D, Phillips LA, et al. CREBBP mutations in relapsed acute lymphoblastic leukaemia. Nature. 2011; 471:235-9. [PubMed: 21390130]

97. Giordano A, Avantaggiati ML. p300 and CBP: partners for life and death. J Cell Physiol. 1999; 181:218-30. [PubMed: 10497301]

98. Goodman RH, Smolik S. CBP/p300 in cell growth, transformation, and development. Genes Dev. 2000; 14:1553-77. [PubMed: 10887150]

99. Ogryzko VV, Schiltz RL, Russanova V, Howard BH, Nakatani Y. The transcriptional coactivators p300 and CBP are histone acetyltransferases. Cell. 1996; 87:953-9. [PubMed: 8945521]

100. Lavau C, Du C, Thirman M, Zeleznik-Le N. Chromatin-related properties of CBP fused to MLL generate a myelodysplastic-like syndrome that evolves into myeloid leukemia. EMBO J. 2000; 19:4655-64. [PubMed: 10970858]

101. Schorry EK, Keddache M, Lanphear N, Rubinstein JH, Srodulski S, Fletcher D, et al. Genotypephenotype correlations in Rubinstein-Taybi syndrome. Am J Med Genet A. 2008; 146A:2512-9. [PubMed: 18792986]

102. Stimson L, Wood V, Khan O, Fotheringham S, La Thangue NB. HDAC inhibitor-based therapies and haematological malignancy. Ann Onco. 2009; 20:1293-302.

103. Pasqualucci L, DD-S, Chiarenza A, Fabbri G, Grunn A, Trifonov V, et al. Inactivating mutations of acetyltransferase genes in B-cell lymphoma. Nature. 2011 in press.

104. Morin RD, Mendez-Lago M, Mungall AJ, Goya R, Mungall KL, Corbett RD, et al. Frequent mutation of histone-modifying genes in non-Hodgkin lymphoma. Nature. 2011

105. Ley TJ, Ding L, Walter MJ, McLellan MD, Lamprecht T, Larson DE, et al. DNMT3A mutations in acute myeloid leukemia. N Engl J Med. 2010; 363:2424-33. [PubMed: 21067377]

106. Mardis ER, Ding L, Dooling DJ, Larson DE, McLellan MD, Chen K, et al. Recurring mutations found by sequencing an acute myeloid leukemia genome. N Engl J Med. 2009; 361:1058-66. [PubMed: 19657110]

107. Mardis ER. A decade's perspective on DNA sequencing technology. Nature. 2011; 470:198-203. [PubMed: 21307932]

108. Trevino LR, Yang W, French D, Hunger SP, Carroll WL, Devidas M, et al. Germline genomic variants associated with childhood acute lymphoblastic leukemia. Nat Genet. 2009; 41:1001-5. [PubMed: 19684603]

109. Papaemmanuil E, Hosking FJ, Vijayakrishnan J, Price A, Olver B, Sheridan E, et al. Loci on $7 \mathrm{p} 12.2,10 \mathrm{q} 21.2$ and $14 \mathrm{q} 11.2$ are associated with risk of childhood acute lymphoblastic leukemia. Nat Genet. 2009; 41:1006-10. [PubMed: 19684604]

110. Gaikwad A, Rye CL, Devidas M, Heerema NA, Carroll AJ, Izraeli S, et al. Prevalence and clinical correlates of JAK2 mutations in Down syndrome acute lymphoblastic leukaemia. Br J Haematol. 2009; 144:930-2. [PubMed: 19120350]

111. Kearney L, Gonzalez De Castro D, Yeung J, Procter J, Horsley SW, Eguchi-Ishimae M, et al. A specific JAK2 mutation (JAK2R683) and multiple gene deletions in Down syndrome acute lymphoblastic leukaemia. Blood. 2008; 113:646-8. [PubMed: 18927438]

112. Cario G, Zimmermann M, Romey R, Gesk S, Vater I, Harbott J, et al. Presence of the P2RY8CRLF2 rearrangement is associated with a poor prognosis in non-high-risk precursor B-cell acute lymphoblastic leukemia in children treated according to the ALL-BFM 2000 protocol. Blood. 2010; 115:5393-7. [PubMed: 20378752]

113. Pui CH, Relling MV, Downing JR. Acute lymphoblastic leukemia. N Engl J Med. 2004; 350:1535-48. [PubMed: 15071128] 


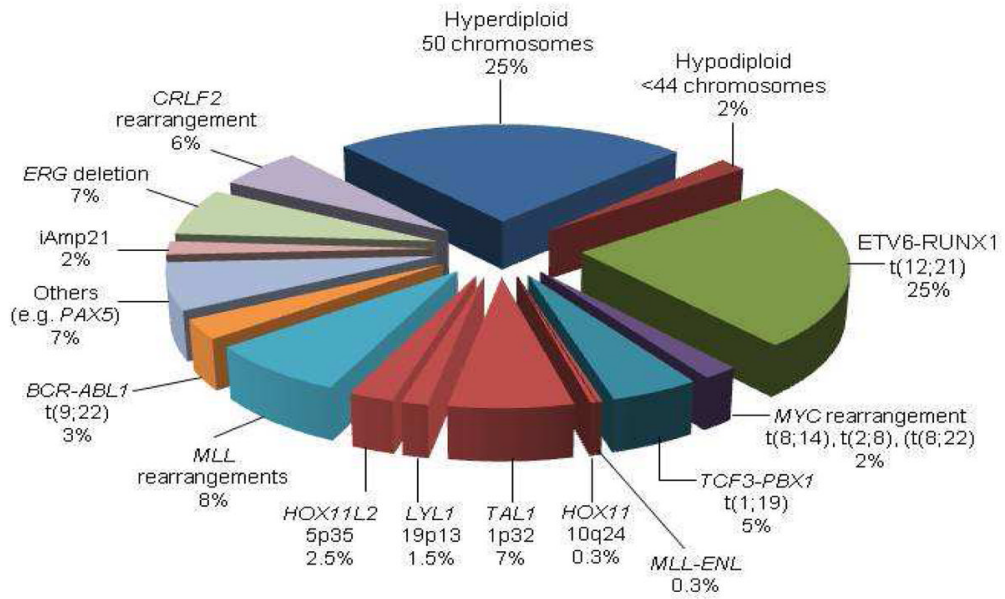

Figure 1. Spectrum of recurring chromosomal rearrangements in childhood ALL

Representation of comment recurring numerical and structural genetic alterations in childhood B-progenitor and T-lineage ALL, including approximate frequencies. Alterations specific to T-lineage ALL are shown at the bottom of the pie chart in magenta. Data are adapted from $[3,113]$. 


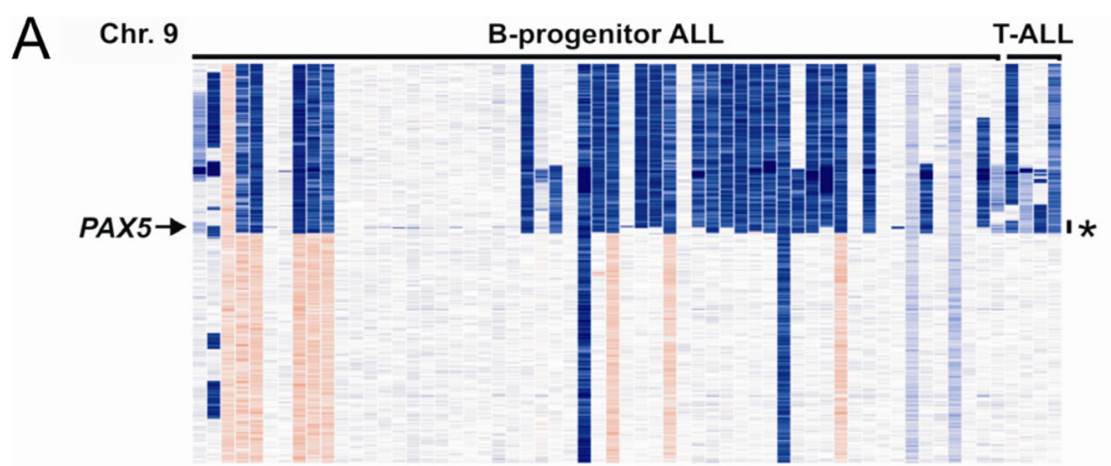

B

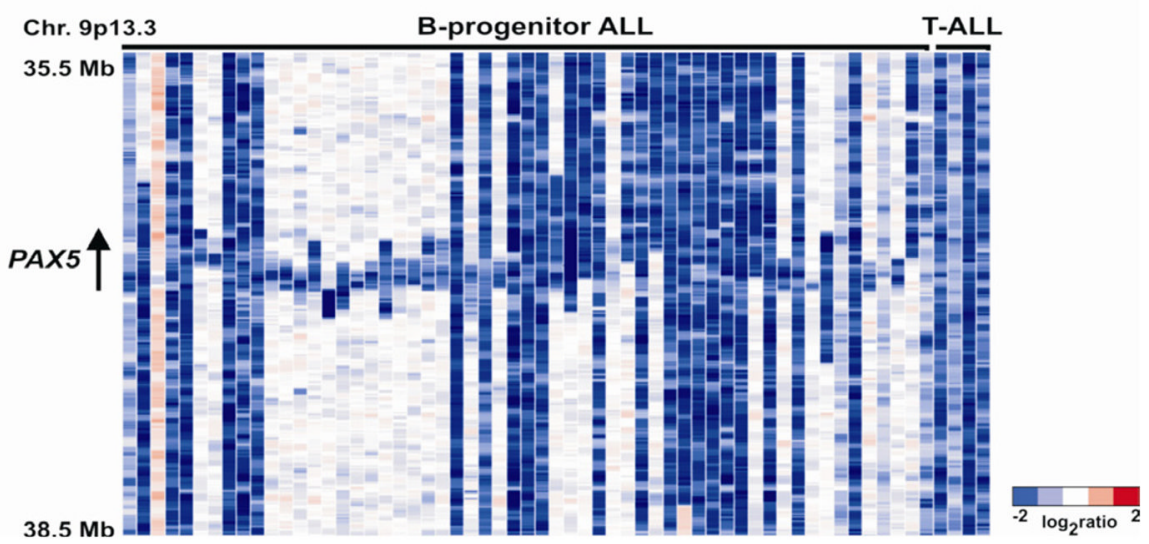



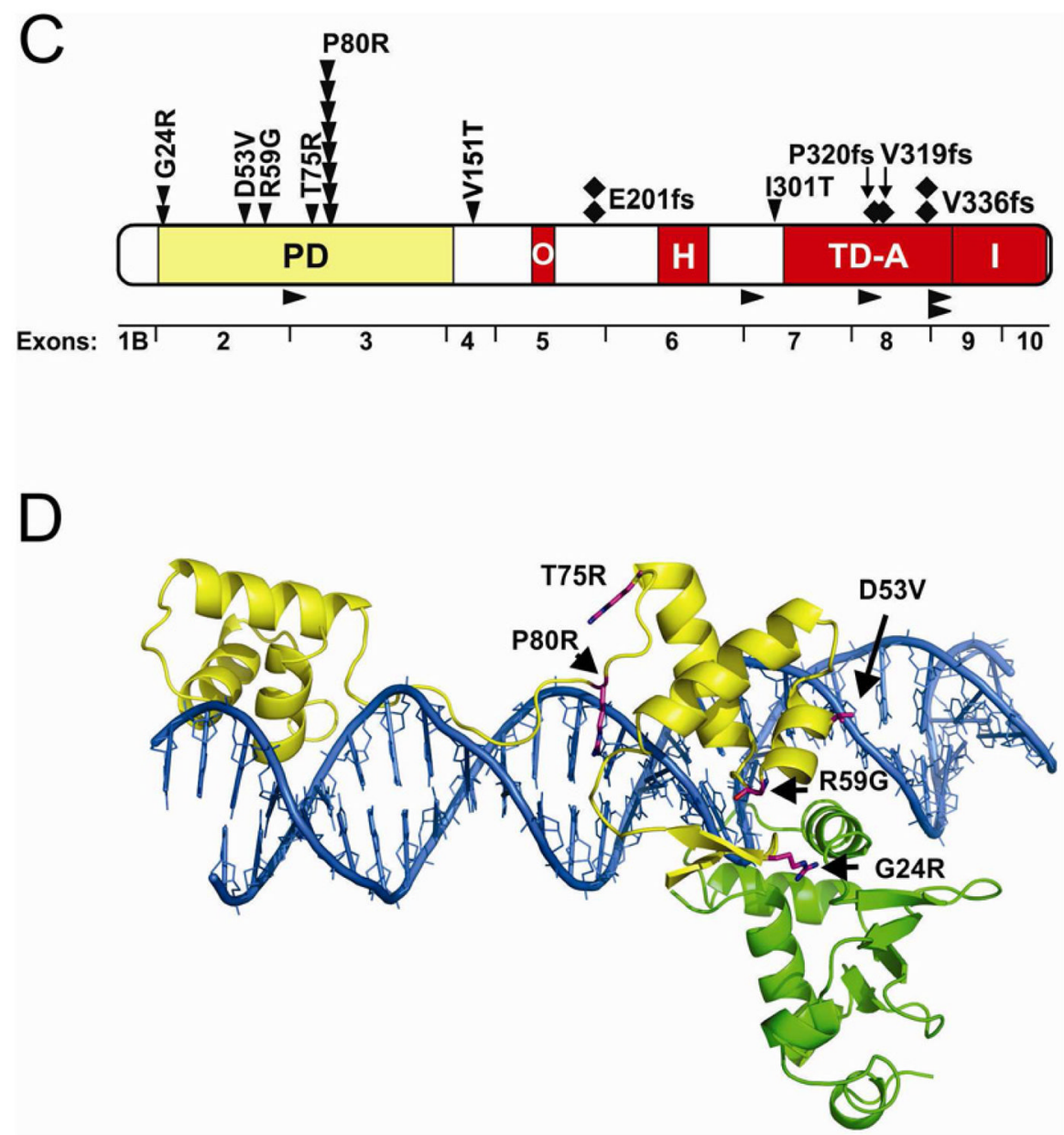

Figure 2. PAX5 alterations in ALL

A. 62 childhood ALL cases with deletions involving PAX5. Many deletions are focal and are not evident on inspection of chromosome-wide data. B. Same data at the PAX5 locus. Data taken from ref [21]. C. PAX5 sequence mutations in high risk B-progenitor ALL, showing missense $(\boldsymbol{\nabla})$, frameshift $(\boldsymbol{)})$, and splice site $(\boldsymbol{)})$ mutations. PD, paired domain; $\mathrm{O}$, octapeptide domain; H, homeodomain; TD, transactivating domain; A, activating; I, inhibitory. D. Structural modeling of the location of PAX5 paired domain mutations. The DNA double helix is blue, the PAX5 paired domain yellow, and ETS-1, which interacts with and increases the affinity of DNA binding of PAX5, is green. Each mutation disrupts normal interaction of PAX5 with DNA and/or ETS-1. Adapted from ref [34]. 


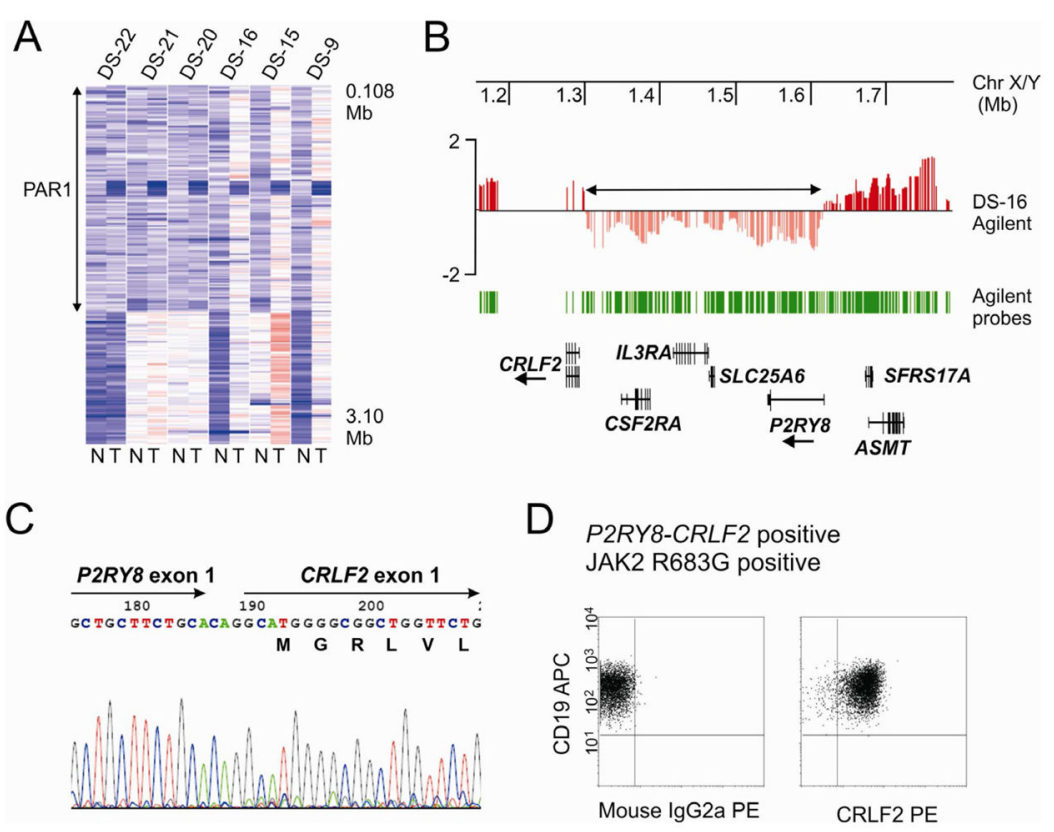

Figure 3. CRLF2 alterations in ALL

A. Focal deletions in the pseudoautosomal 1 region of Xp/Yp. SNP 6.0 log ratio copy number data for 6 Down syndrome ALL cases with matched tumor $(\mathrm{T})$ and normal $(\mathrm{N})$ data are shown. Light blue shows focal PAR1 deletion is present, the extent of which is identical in all cases. B. Mapping of the PAR1 deletion (probe level data are shown as vertical red lines) to between intron 1 of $P 2 R Y 8$ and upstream of CRLF2. C. The PAR1 deletion results in a $P 2 R Y 8-C R L F 2$ fusion containing the entire CRLF2 open reading frame. D. The $P 2 R Y 8$ $C R L F 2$ fusion results in CRLF2 overexpression that may be detected by immunophenotyping of leukemic cells. 


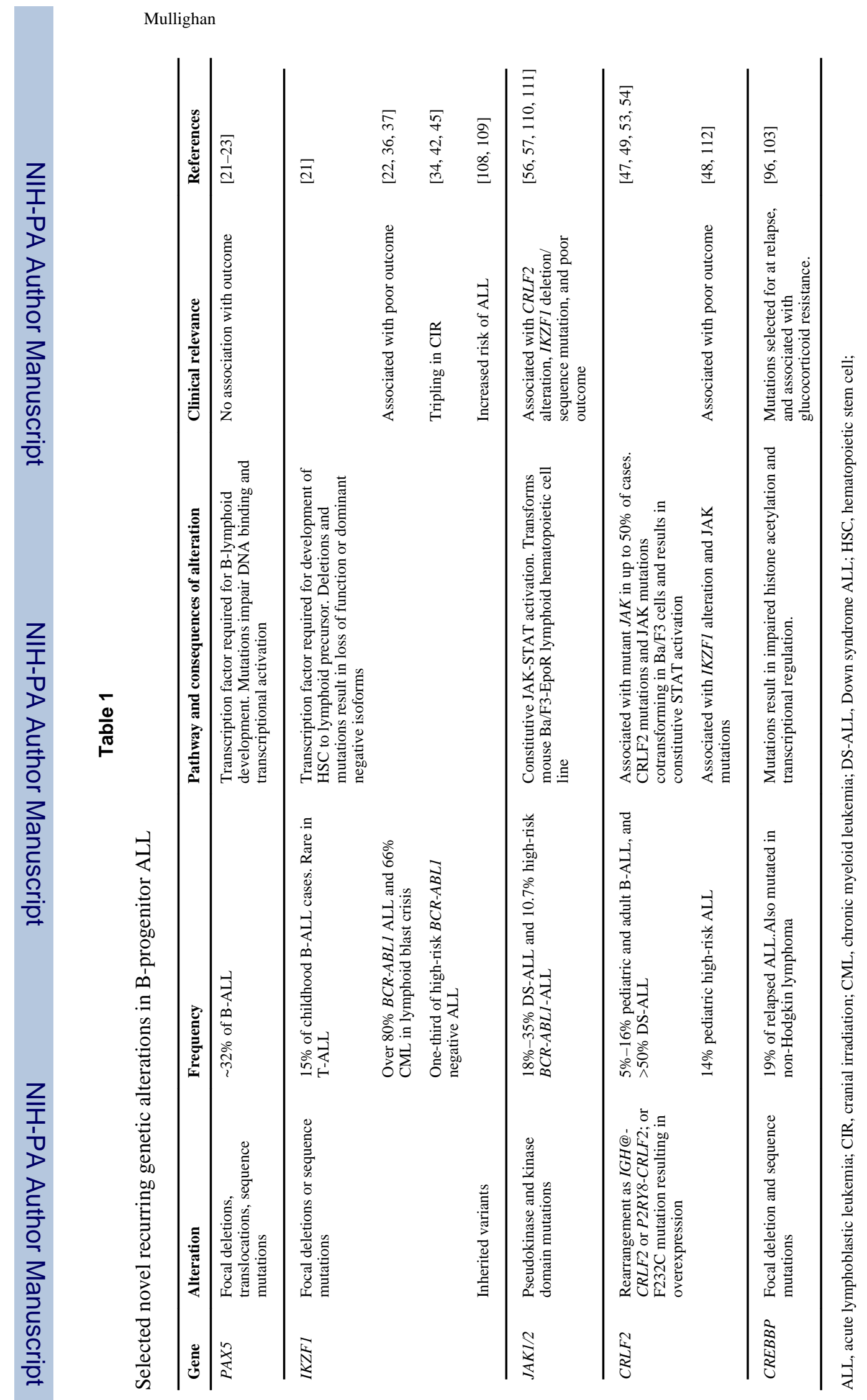

Best Pract Res Clin Haematol. Author manuscript; available in PMC 2012 December 1. 